\title{
Mastermind-like 1 (MAML-1) as a new metastatic marker in esophageal squamous cell carcinoma
}

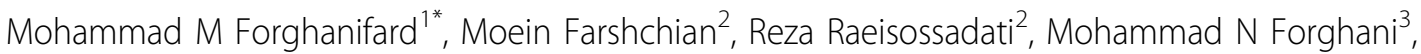 \\ Meysam Moghbeli², Hussein Naseh ${ }^{4}$, Mohammad R Abbaszadegan ${ }^{2}$ \\ From 16th International Charles Heidelberger Symposium on Cancer Research \\ Coimbra, Portugal. 26-28 September 2010
}

Deregulation of the normal cellular processes that mediate cell proliferation, differentiation and death programs, have been seeing in various tumor cell types [1]. Notch signaling pathway that plays fundamental roles in definition of the cell fate and self-renewal is frequently deregulated in human malignancies, by up or down regulation, where it may act either as an oncogene or as a tumor suppressor depending on the cell context $[2,3]$. The MAML proteins are transcriptional co-activators of notch signalling that are not only essential for related responses, but also have some regulatory functions in other signaling pathways, including p53 and Wnt/beta-catenin, and therefore have a central role in signaling cross talk of diverse cellular processes such as cell proliferation, differentiation and survival [4].

In current study, the expression of MAML-1 and EGFR genes were analyzed in 44 esophageal squamous cell carcinoma (ESCC) patients with the quantitative (real-time) RT-PCR. Overexpression of these genes was found in $45.5 \%$ and $38.6 \%$ of ESCC samples respectively. Relative expression of MAML-1 was significantly associated with the lymph node metastasis of tumor cells $(\mathrm{P}<0.05)$.

Since MAML-1 is an essential transcription coactivator of notch signaling pathway and downstream related genes expression, we extrapolated that, notch signaling may contribute in tumor development and metastasis in ESCC, however further studies are required. We report for the first time that MAML-1 gene is overexpressed as a metastasis-related gene in ESCC samples. This indicates that MAML-1 may be a possible metastatic marker

\footnotetext{
* Correspondence: forghanifard@gmail.com

'Department of Biological Science, Islamic Azad University, Damghan Branch, Damghan, Iran (Islamic Republic of)

Full list of author information is available at the end of the article
}

of ESCC and a possible good therapeutic target in order to block tumor cell metastasis.

\section{Author details}

'Department of Biological Science, Islamic Azad University, Damghan Branch, Damghan, Iran (Islamic Republic of). ${ }^{2}$ Human Genetic Division, Immunology Research Center, Avicenna Research Institute, Mashhad University of Medical Sciences. Mashhad, Iran (Islamic Republic of). ${ }^{3}$ Department of Surgery, Omid Hospital, MUMS, Mashhad, Iran (Islamic Republic of). ${ }^{4}$ Department of Pathology, Omid Hospital, MUMS, Mashhad, Iran (Islamic Republic of).

\section{Published: 24 September 2010}

\section{References}

1. Allenspach EJ, Maillard I, Aster JC, Pear WS: Notch signaling in cancer. Cancer Biol Ther 2002, 1:466-476.

2. Koch U, Radtke F: Notch and cancer: a double-edged sword. Cell Mol Life Sci 2007, 64:2746-2762.

3. Bolós V, Grego-Bessa J, de la Pompa JL: Notch signaling in development and cancer. Endocr Rev 2007, 28:339-363.

4. McElhinny AS, Li J-L, Wu L: Mastermind-like transcriptional co-activators: emerging roles in regulating cross talk among multiple signaling pathways. Oncogene 2008, 27:5138-5147.

\section{doi:10.1007/s00018-007-7164-1}

Cite this article as: Forghanifard et al:: Mastermind-like 1 (MAML-1) as a new metastatic marker in esophageal squamous cell carcinoma. BMC Proceedings 2010 4(Suppl 2):P3.

Submit your next manuscript to BioMed Central and take full advantage of:

- Convenient online submission

- Thorough peer review

- No space constraints or color figure charges

- Immediate publication on acceptance

- Inclusion in PubMed, CAS, Scopus and Google Scholar

- Research which is freely available for redistribution 